Article

\title{
Variation in Seed Harvest Potential of Carapa guianensis Aublet in the Brazilian Amazon: A Multi-Year, Multi-Region Study of Determinants of Mast Seeding and Seed Quantity
}

\author{
Christie A. Klimas ${ }^{1, *(1)}$, Lúcia Helena de Oliveira Wadt ${ }^{2}$, Carolina Volkmer de Castilho ${ }^{3}$, \\ Ana Cláudia Lira-Guedes ${ }^{4}$, Patricia da Costa ${ }^{5}$ (-) and Fernanda Lopes da Fonseca ${ }^{6}$ \\ 1 Environmental Science and Studies Department, DePaul University, McGowan South 203, 1110 West Belden \\ Ave., Chicago, IL 60601, USA \\ 2 Embapa Rondônia, Porto Velho 76815-800, RO, Brazil; lucia.wadt@embrapa.br \\ 3 Embrapa Roraima, Boa Vista 69301-970, RR, Brazil; carolina.castilho@embrapa.br \\ 4 Embrapa Amapá, Macapá 68903-419, AP, Brazil; ana-lira.guedes@embrapa.br \\ 5 Embrapa Meio Ambiente, Jaguariúna 13918-110, SP, Brazil; patricia.da-costa@embrapa.br \\ 6 Embrapa Acre, Rio Branco 69900-970, AC, Brazil; fernanda.fonseca@embrapa.br \\ * Correspondence: cklimas@depaul.edu; Tel.: +1-773-325-8423
}

\section{check for}

updates

Citation: Klimas, C.A.; Wadt,

L.H.d.O.; Castilho, C.V.d.;

Lira-Guedes, A.C.; da Costa, P.; da

Fonseca, F.L. Variation in Seed

Harvest Potential of Carapa guianensis

Aublet in the Brazilian Amazon: A

Multi-Year, Multi-Region Study of

Determinants of Mast Seeding and

Seed Quantity. Forests 2021, 12, 683.

https://doi.org/10.3390/f12060683

Academic Editor: Nikos Nanos

Received: 15 March 2021

Accepted: 19 May 2021

Published: 27 May 2021

Publisher's Note: MDPI stays neutral with regard to jurisdictional claims in published maps and institutional affiliations.

Copyright: (C) 2021 by the authors Licensee MDPI, Basel, Switzerland. This article is an open access article distributed under the terms and conditions of the Creative Commons Attribution (CC BY) license (https:// creativecommons.org/licenses/by/ $4.0 /)$.

\begin{abstract}
This work augments research on masting for the economically important tropical tree Carapa guianensis Aublet, specifically on whether determinants of mast years vary regionally, spatially, and due to longer term ENSO climate patterns. Longer term measurements (an 11-year period in Acre and Roraima; 4 years and 8 months in Amapá) from three regions of the Brazilian Amazon allowed for the analysis of whether climate cues were regionally consistent for this species. We used generalized linear mixed models, to determine which factors were significant in predicting whether trees would produce in a given year and to model the seed production quantity. We found a positive effect of increasing the diameter at breast height $(\mathrm{dbh})$ on the quantity and likelihood of seed production. Our results also suggested that ecosystems and climate cues may jointly affect seed production. In flooded forests, increases in dry season rainfall had a negative impact on the likelihood of seed production whilst none of the precipitation variables investigated influenced the quantity of seeds produced. In drier terra firme forests in Acre with extended dry seasons, increases in dry season precipitation had significant and positive impacts on both the likelihood and the quantity of seed production. Our results illustrate the importance of considering plant habitat and climate to better understand individual and regional differences in seed production and their responses to inter-annual climate variation.
\end{abstract}

Keywords: non-timber forest products; forest management; multi-use species

\section{Introduction}

Incentives to clear tropical forests for extractive activities like mining [1-3], cattle ranching [4], and large-scale agricultural production [5,6] have led to global forest loss. Commodity-driven deforestation is especially prevalent in Latin America, where it is responsible for an estimated $64 \pm 8 \%$ of deforestation, compared to only $27 \pm 5 \%$ globally [7]. Governments often incentivize or turn a blind eye to the impacts of this commodity-driven deforestation due to its associated economic benefits [2,8,9] or for political reasons [10]. Examples of governmental policies that encourage forest removal include programs that provide access to credit for cattle production [11] and development projects that do not consider the reality of traditional Amazonian communities, and thus are not implemented [12,13]. However, there are economic alternatives that are less ecologically destructive. Along the Transamazon highway, smallholders practicing family agriculture and subsistence farming converted (deforested) 35\% of their landholdings in comparison capitalized cattle ranchers who converted $85 \%$ of their larger landholdings [11]. Non-timber forest products (NTFPs), 
often literally called fruits of the forest, can also provide economic benefit [14-17] and maintain forest cover and species persistence even under high harvest levels $[18,19]$. While often unrecognized in national statistics, NTFP harvest can benefit the high proportions of rural households; $83 \%$ of rural households collected the edible Dioscorea hirtiflora Benth. in Southern Zambia and 96\% consumed these tubers [20]. While the revenue of NTFP harvest alone is not equivalent to income from more destructive extractive activities [21], NTFP harvest can be part of multi-use forest management strategies to help safeguard valuable ecosystem services like tree carbon storage and sequestration [22,23]. Ecosystem service provision may be remunerated via programs like payments for ecosystem services (PES) [24] or other efforts to more fully incorporate the full value of forests into decisionmaking [25]. These payments can provide an opportunity for small farmers and forest residents to continue forest management with its concurrent environmental benefits.

Income associated with NTFP collection can vary due to ecological variables like what product is harvested for a given species [26,27], or market variables like the existence of linked production chains, market networks and informal financing [26]. Seasonal or annual production variability [28,29], and spatial [30] or regional production variation [31] can contribute to income variation. This is especially true for masting species, those characterized by synchronized and highly variable seed production within a population or community [32].

Carapa guianensis (Meliaceae) Aublet. is one such masting species, though large synchronized mast events do not preclude $C$. guianensis seed production in other years [30]. Considered a multi-use tropical tree, $C$. guianensis is economically valued for its quality timber $[33,34]$ and the repellent $[35,36]$ and medicinal properties of its seed oil $[37,38]$. Since long-term storage is not an option for C. guianensis seeds [39], advanced knowledge of high seed production years can allow for infrastructure investment [40] for manual seed oil extraction and time allocation for expressing the oil. It can also allow for the coordination of market partnerships as larger quantities of seeds or seed oil can be sold outside the local market with advanced planning. Better understanding the determinants and predictors of mast years in C. guianensis is therefore both an important addition to ecological research and has economic implications due to the revenue associated with $C$. guianensis seed oil extraction.

Intra-annual climate variation has led to distinctive seasonal phenologies in tropical trees like the common pattern of new leaf flush at the beginning of the dry season [41] and seed production early in the wet season [42]. In Nouragues, French Guiana, the fruiting peak of 22 of 45 species occurred at the peak of the rainy season [43]. A two-year study in the Amazon Estuary in the municipality of Macapá, Amapá, Brazil, found the peak period for C. guianensis seed production to be from March to May, during the wettest months of the year [39]. C. guianensis flowering occurred during the dry season in Amapá [44], Pará [45], Roraima [46], and a population in Acre, Brazil [47]. Two flowering peaks were observed in the dry and rainy season in Acre [30] and flowering during the rainy season was also observed at the Tembé Indigenous Reserve in Pará state [48]. However, all these studies $[30,39,44-48]$ measured peak $C$. guianensis fruiting during the rainy season. Carapa guianensis's seasonality of phenology is consistent with the hypothesis that many tropical trees time flowering to coincide with the annual dry season irradiance peak and to avoid the prolonged wet-season irradiance low $[42,49]$. This phenological seasonality, common in humid tropical forests, also facilitates hydrochorous seed dispersal, or reliance on water transport.

While $C$. guianensis peak fruitfall timing coincides with the rainy season across parts of the Brazilian Amazon, it is unclear whether the cues for rainy season fruitfall are the same in each region. Climate cues are not always consistent across masting species or even spatially consistent for the same species [31] or family [50]. In a floodplain forest, in Amapá, Brazil, the proportion of C. guianensis trees flowering was strongly and significantly negatively related to the total rainfall [39], though there is little research on the cues behind C. guianensis phenological patters in other areas of the Amazon. [51]. Carapa 
guianensis is a flower masting species where seed production is determined by variable flower production [51]. With flower masting species, temperature, irradiance, and rainfall both prior to and during flowering can affect seed production. Climate cues prior to flower production lead to buds; conditions during flowering help synchronize pollination and lead to fruit production [31].

Additionally, fruiting may be affected by larger-scale climate patterns like the El Niño Southern Oscillation (ENSO). El Niño years bring reduced rainfall and cloud cover and increased temperature and solar irradiance. La Niña years are characterized by the opposite: higher rainfall and cloud cover coupled with decreased temperature and solar irradiance [52]. Since seasonal irradiance during the dry season can facilitate net primary production by reducing light limitation [41,53], moderate El Niño events can favor seed production [41,53], though more severe El Niño years, with associated droughts and fires, have increased tree mortality [54,55].

Better understanding the frequency, quantity, and variability of annual seed production allows for more realistic estimates of expected income for forest managers. Therefore, one study objective is to determine the importance of climate cues in predicting whether trees produce in a given year (masting), and for those that do produce, the variables important in determining the quantity of seed produced. More specifically, we hypothesized that rainfall in both the year of flowering and the year prior to flowering would be significant determinants of masting since both would affect the resources available for flowering, a necessary pre-requisite for fruiting in this flower-masting species. Specifically, we hypothesized that: (1) wet season rainfall prior to flowering would be significantly and positively correlated with total seed production in that year. Due to physiological constraints, termed resource matching, we hypothesized that: (2) non-mast years would follow mast events due to the necessity of Carapa guianensis to replenish reserves sufficient for seed production. We hypothesized that: (3) the cues for masting would be consistent across the three study regions due to the fact that peak $C$. guianensis seed production occurs in the rainy season across habitat types: floodplain forests, terra firme [39], and occasionally inundated forests [30]. Based on previous studies, we also hypothesized that (4) there would be a significant, positive relationship between each diameter at breast height (dbh) [30,56,57] and canopy area [58] with mean seed production per tree. Finally, we hypothesized (5) a negative relationship between El Niño and seed production independent of masting phenomenon $[41,59]$ due to research indicating that larger seeded species were the least resilient to ENSO-induced drought [59]. Similarly, we hypothesized a positive relationship on seed production during La Niña events/years.

We report findings from a spatially and temporally extensive C. guianensis seed production dataset. Long-term measurements of phenology and seed production are still a relative rarity in the tropics, though more information can be found in [41,53]. This work augments research on masting for an economically important tropical tree, specifically information on whether determinants of mast years vary regionally, spatially, and due to longer term ENSO climate patterns. The effect of different ecosystems (or habitat) could not be determined using statistics since we do not have a sufficient replication of the habitats. In our results, however, we report patterns by ecosystem.

\section{Materials and Methods}

Seed production was measured in 3 Amazonian regions: a floodplain forest in Amapá [39], a tropical rainforest with a short dry season in Roraima [60], and two forest types in Acre, Brazil: seasonally inundated and terra firme forests. While there are some gaps in the data collection, seed production was measured during an 11-year period in Acre and Roraima, and for 4 years and 8 months in Amapá.

\subsection{Species Description}

Carapa guianensis (Meliaceae) is hardwood tree with an extensive range that includes tropical Africa, Central America south of Honduras-including many parts of the Amazon 
region-the West Indies, and Antilles [61,62]. In Brazil, C. guianensis is found in three habitat types: terra firme, seasonally or occasionally inundated, and floodplain forest $[39,44,60,63]$, with evidence of higher densities in wet areas [63,64]. At maturity, C. guianensis can attain up to $55 \mathrm{~m}$ in height [63].

Fruits are spherical or subspherical dehiscent capsules with four to six valves, each containing one to four seeds $[30,61]$. Valves separate after seeds fall to the ground, releasing enclosed seeds. Like other species that show fruiting peaks at the beginning of the rainy season $[42,53,65]$, hydrochorous seed dispersal is partially responsible for seed transport to favorable germination locations and the avoidance of seed clusters that facilitate Hypsipyla ferrealis Hampson and Hypipyla grandella Zeller moth predation [66]. Frugivores, including the collared (Tayassu tacaju Linnaeus) and white-lipped peccaries (Tayassu pecari Link), agoutis and acouchis (Dasyprocta sp.), pacas (Cuniculus sp.) and armadillos [39], are also responsible for secondary seed dispersal, and seed consumption [60,61].

Considered a multi-use species $[33,67]$ due to its high-quality timber and oil extracted from seed, C. guianensis has social, economic, and cultural relevance to Amazonian populations and forest extractivist residents. The seed oil has local and international demand and is used for soap and candle production (due to its efficacy as a mosquito repellent), as a component in cosmetics, and as a popular medicine. Medicinally, the oil is used to counter inflammation, as an insecticide due to its repellent activity, and a vermifuge, to expel parasitic worms from the body [36,63]. Tea from C. guianensis bark and leaves is used as treatment for infection and foot diseases [68]. Modeled management scenarios indicate a positive revenue from combined C. guianensis timber and seed harvest [69] though economically viable timber and seed harvest levels may not be compatible with species maintenance without silvicultural interventions [15].

\subsection{Tree Selection and Seed Production Quantification Methodology}

\subsubsection{Acre}

The methodology for the Carapa guianensis inventory [64] and quantification of seed production in Acre has been detailed elsewhere [30]. Due to variation in seed production, it was necessary to quantify year-round seed production in Acre, although it is likely that seed collection will only occur during the period leading up to and following the peak annual production to maximize the return from the expended collection effort. In summary, over 1300 C. guianensis trees were inventoried in four $400 \times 400 \mathrm{~m}$ plots, two plots in terra firme forests, and two plots in occasionally inundated forests $\left(10^{\circ} 01^{\prime} 28^{\prime \prime} \mathrm{S}, 67^{\circ} 42^{\prime} 19^{\prime \prime} \mathrm{W}\right)$ [64]. For the quantification of seed production, a subset of inventoried trees was selected in two forest types and 4 diameter classes: $15-20 \mathrm{~cm} ; 20-30 \mathrm{~cm} ; 30-40 \mathrm{~cm}$; and $>40 \mathrm{~cm}$. All selected trees had evidence of production (i.e., buds, flowers, or immature fruits), did not drop their seeds into a river, and had canopies that did not overlap with conspecifics. No trees were selected in the 10-15 cm diameter class since no evidence of seed production was found for these smaller diameter trees [30]. The number of individuals monitored for seed production in Acre increased from 38 in November 2004 to a maximum of 105 in June 2006 (Table 1). By the end of monitoring in 2015, the death of monitored individuals resulted in 98 observed trees (Table 1 ).

Quantifying seed production prior to December 2010 included clearing the ground below monitored individuals to deter seed predators and collect all fallen seeds. Seeds were weighed and counted in the lab [30]. Beginning in December 2010, the seeds were placed in plastic bags and weighed in the field using a 10 or $20 \mathrm{~kg}$ spring scale. Seeds that were not viable (aborted from the tree or attacked by predators) were not weighed. To determine seed dry weight and the percent of seed water content, a sample of five seeds was taken from each tree. These samples were then weighed at an onsite laboratory for wet weight, dried for $24 \mathrm{~h}$ at 105 degrees Celsius, and then reweighed to determine the dry weight. This percent conversion to dry weight was used for all trees sampled on that day (in a given plot). Separate conversions were done if it rained between collections on the same day or if seeds fell into the water (thus affecting their percentage dry weight in 
comparison with other seeds). In these cases, percentage dry weight was calculated by collecting all seeds and recording both wet and dry weight in the laboratory. Seed wet and dry weight were also recorded for all trees that had a seed production of less than 5 seeds in a given week.

Table 1. The number of Carapa guianensis trees in Acre, Roraima, and Amapá, Brazil, monitored for annual estimates of seed production and the time period during which seed production was quantified for each region and the year of the study.

\begin{tabular}{cccc}
\hline Location & Quantification Period & Measurement Period & Number of Trees \\
\hline & November 2004-March 2005 & 17 weeks & 39 \\
& January 2005-February 2006 & 5 weeks & 77 \\
& November 2006-February 2007 & Continuous & 105 \\
& $2007-2008$ & Continuous & 104 \\
Acre & $2008-2009$ & Continuous & 103 \\
& October 2010-October 2011 & Continuous & 103 \\
& January 2013-July 2013 & 26 weeks & 99 \\
& July 2013-February 2014 & 34 weeks & 99 \\
March 2014-November 2015 & Continuous & 114 \\
Roraima & May-August 2006 & 12 weeks & 114 \\
& April-July 2007 & 13 weeks & 114 \\
& April-September 2008 & 20 weeks & 114 \\
& April-July 2009 & 12 weeks & 114 \\
& April-September 2010 & 20 weeks & 114 \\
& April-August 2011 & 14 weeks & 114 \\
& April-June 2012 & 9 weeks & 114 \\
\hline
\end{tabular}

\subsubsection{Roraima}

In Roraima, all C. guianensis trees with a dbh equal or greater than $10 \mathrm{~cm}$ were mapped and measured in a 9 ha permanent plot $(300 \mathrm{~m} \times 300 \mathrm{~m})$ established in a terra firme forest $\left(00^{\circ} 57^{\prime} 02^{\prime \prime} \mathrm{N} 59^{\circ} 54^{\prime} 41^{\prime \prime} \mathrm{W}\right)$. A total of 145 individuals were marked at the first census in 2006 and an additional individual was added at a 2008 census for a total of 146 trees selected for seed production quantification from 2008 to 2012 and 2017. Mortality decreased this number over the study period, leaving 133 trees in 2017 (Table 1). C. guianensis trees were visited periodically (normally every two weeks to monthly) during the production period (Table 1). To quantify seed production, all seeds fallen under the crown projection area of each monitored tree were weighed in the field using a 10 or $20 \mathrm{~kg}$ spring scale (precision $\pm 50 \mathrm{~g}$ ). Since only reproducing trees were included at the Acre and Amapá field sites, all individuals that did not produce any seeds during the monitored period were removed from the Roraima data. One hundred and eleven trees with evidence of seed production were used for modeling.

\subsubsection{Amapá}

In Amapá, a complete tree inventory was completed in a 55.94-hectare estuarine floodplain forest $\left(00^{\circ} 6^{\prime} 54^{\prime \prime} \mathrm{S}\right.$ and $\left.51^{\circ} 17^{\prime} 20^{\prime \prime} \mathrm{W}\right)$. Following the inventory, $16 \mathrm{C}$. guianensis individuals were selected to monitor seed production. Three criteria were necessary for selection: (1) tree canopy did not overlap with other conspecifics; (2) excellent tree health; and (3) the canopy did not partially or completely extend over one of the streams crossing the area. All trees meeting these selection criteria were enclosed with $1.2 \mathrm{~m}$-high plastic screens/fences with the enclosure encompassing the entire area below the canopy to avoid animal predation or the water transport of seeds. This avoided the over- or underestimation of seed production from predation and water transport. Selected trees were visited every 15 days from 2011 to 2016. 


\subsection{Converting to Seed Dry Weight}

For the Acre data, we multiplied the wet weight by 0.674 to convert to dry weight based on measurements during the period 2004-2009 [30]. For Amapá, both wet and dry weight were measured during the period 2011-2016. The conversion factor was 0.890 times the wet seed weight. In Roraima, seed weight was measured in the field. To convert from seed wet to dry weight, we used the average of our conversion factors in Amapá and Acre (0.782).

\subsection{Tree Attributes and Climatic Variables}

At all sites, diameter at breast height (dbh) was measured for each C. guianensis monitored for seed production. At the Embrapa field site in Acre, we also measured the crown cross-sectional area [30], and we tested this as a potential predictor variable for seed production.

For climate data that corresponded with the location of seed production measurements, we downloaded monthly precipitation and temperature data (averaged per month) at Brazil's National Meteorological Institute [70] in text file format from the nearest station to each seed collection site. Data included total monthly precipitation, averaged daily maximum temperature, averaged daily minimum temperature, and averaged daily temperatures for a given month. Seed production data in Roraima was collected in the municipality of São João da Baliza. While we had precipitation data for this municipality, the closest climate station to this site (for temperature data) was in Caracarai $\left(01^{\circ} 49^{\prime} 48^{\prime \prime} \mathrm{NE}\right.$ $\left.61^{\circ} 07^{\prime} 12^{\prime \prime} \mathrm{W}\right)$ at an altitude of $60 \mathrm{~m}$. In Acre, near the Embrapa field site at Km 14 on Highway BR-364, the closest climate station was in Rio Branco, Acre's capital city ( $09^{\circ} 57^{\prime} 36^{\prime \prime}$ SE $67^{\circ} 48^{\prime} 00^{\prime \prime} \mathrm{W}$ ) at an altitude of $160 \mathrm{~m}$. In Amapá, the study area was a 55.94-hectare estuarine flooded forest at Emprapa Amapá's experimental field site $\left(00^{\circ} 06^{\prime} 54^{\prime \prime}\right.$ SE $\left.51^{\circ} 17^{\prime} 20^{\prime \prime} \mathrm{W}\right)$, in the Mazagão municipality. The closest climate station, Climate Station Fazendinha, was in Macapá (-0.05 latitude, -51.11 longitude).

We included site-specific temperature and precipitation as potential predictor variables in our seed production model: (a) summed annual precipitation; (b) annual average of the daily maximum temperature; (c) annual average of the daily minimum temperature; (d) annual average of the daily average temperature. We also included summed precipitation during the (e) dry and (f) wet season. We defined the dry season as consecutive months with precipitation equal to or less than $100 \mathrm{~mm}$, or approximately $3.5 \mathrm{~mm}$ per day [71], beginning the year prior to seed collection data and continuing through the end of seed collection. These dry periods varied in duration and time from year to year (Table S1), so we also included dry season duration and the duration of the dry season in the previous year as additional predictor variables. We defined the wet season as the three months with the highest average rainfall during the same period. While there was variation (Table S1), the wet season normally occurred during the January-March period in Acre; May-July in Roraima; and February-April in Amapá.

Temperature and precipitation both in the year that seeds develop and produce and in the previous years that can affect seed production [72,73]. We therefore included three sitespecific variables from the year prior to seed production: (a) summed annual precipitation; (b) summed dry season precipitation; and (c) summed wet season precipitation (i.e., a 2004 summed precipitation for seed production occurring in 2005). All climatic variables are shown in Table S1.

\subsection{Data Analysis}

Our data included both fixed and random effects. Since seed production was measured per tree over multiple years, the time period and repeated measures (multiple values of seed production measured per tree) were random effects. Seed production data were not normal. Most trees produced smaller masses of seeds, with a long tail; some $C$. guianensis individuals were prolific producers. A study of C. guainensis in Roraima found that individual production varied from $300 \mathrm{~g}$ to $63.9 \mathrm{~kg}$ [60]. Indeed, a small subset of fecund 
individuals is often responsible for "a high proportion of overall fruit production" [74]. As "generalized linear mixed models (GLMMs) are the best tool for analyzing non-normal data that involve random effects" [75], we modeled seed production with GLMMs with tree and time period as random effects.

The variance in seed production was larger than the mean, termed overdispersion. This was partially due to zero-inflation, a larger number of zeros in the dataset than expected. Trees that did not produce were true zeros, not artifacts of sampling methodology or methodological errors. When zero-inflation is caused by true zeros, it is useful to model the zeros and counts separately [76]. In our dataset, the percentage of trees with no production in a given year is of biological interest due to the fact that $C$. guianensis is a masting species. Better understanding the factors that affect the likelihood of masting is of ecological interest. We were also interested in the variables that affected the quantity of seed production for those trees that produced. Therefore, we used a hurdle model. Hurdle models model the outcome as having two stages [77], which can be modeled separately. The first part of the model estimates the probability that the zero threshold is crossed, or whether $C$. guianensis reproductive individuals do (1) or do not produce seeds (0). We used the logit model (i.e., a binomial model) to determine which factors were significant in predicting whether trees would produce seeds in a given year. A generalized linear mixed model takes the form:

$$
y=X \beta+Z u+\varepsilon
$$

where $y$ is a $N \times 1$ column vector, the outcome variable, $X$ is a $N \times p$ matrix of the $p$ predictor variables, $\beta$ is a $p \times 1$ column vector of the fixed-effects regression coefficients, and $Z$ is the $N \times q$ design matrix for the $q$ random effects, $u$ is a $q \times 1$ vector of the random effects, and $\varepsilon$ is a $N \times 1$ column vector of the residuals. The generalized linear mixed model for predicting whether or not trees produced was:

$$
\begin{gathered}
Y_{i j} \sim \operatorname{Binomial}\left(1, p_{i j}\right) \\
\operatorname{logit}\left(p_{i j}\right)=\alpha+\beta_{1} \text { Tree }_{\text {attributes }} i j \\
+\beta_{2} x \text { Climatic variables }_{i j}+\beta_{3} x \text { ENSO }_{i j}+a_{i} \\
a_{i} \sim N\left(0, \sigma_{a}^{2}\right)
\end{gathered}
$$

$Y_{i j}$ is 1 if individual/tree $\mathrm{j}$ produces in year $i$ and 0 otherwise. The random intercept $\mathrm{a}_{\mathrm{i}}$ is assumed to be normally distributed with a mean 0 and variance $\sigma_{a}^{2}$ [77]. Tree attributes and climatic variables represent multiple potential variables. For example, tree attributes include the $\mathrm{dbh}$ and cross-sectional canopy area. Climatic variables are detailed in the methods. ENSO represents two variables, either the presence/absence of an El Niño year (modeled as a separate model due to correlation between climatic variables and ENSO), and the presence/absence of a La Niña year.

If there was evidence of seed production, the "hurdle" was crossed and a generalized linear mixed model was used to model the quantity of seeds produced (in grams) for producing C. guianensis individuals. We first used the packages fitdistrplus [78] and logspline [79] to determine which distributions were most appropriate for modeling the quantity of seed production within the mixed model. We found that a gamma distribution was most appropriate for representing seed production (see results). All statistical analysis was done using R [80] and we used the package glmmTMB for the generalized linear mixed effects model with a gamma distribution [81] due to its ability to handle random effects (year) and tree identification (repeated measures). Prior to running the models, we tested for collinearity between predictor variables. Variables were excluded when they were highly correlated with other variables.

\section{Results}

Annual seed production (in grams) varied temporally at each of the three sites with high variability around the mean during years of high production (Figure 1a-c). The 
differences in the quantity of seed production between individuals were graphed in Acre (Figure 2a-i), Amapá (Figure 3a-e), and Roraima (Figure 4a-h). Figures 2-4 also show dbh and seed production patterns. While there is no clear relationship between $\mathrm{dbh}$ and seed production during years of low seed production (Figure 2, 2006 and 2009 panels), there is evidence of high production by large dbh individuals in mast years (Figure 4, 2006, 2008, 2009, and 2011 panels), but also evidence of high production at the intermediate dbh (Figure 2, 2005 and 2013 panels).

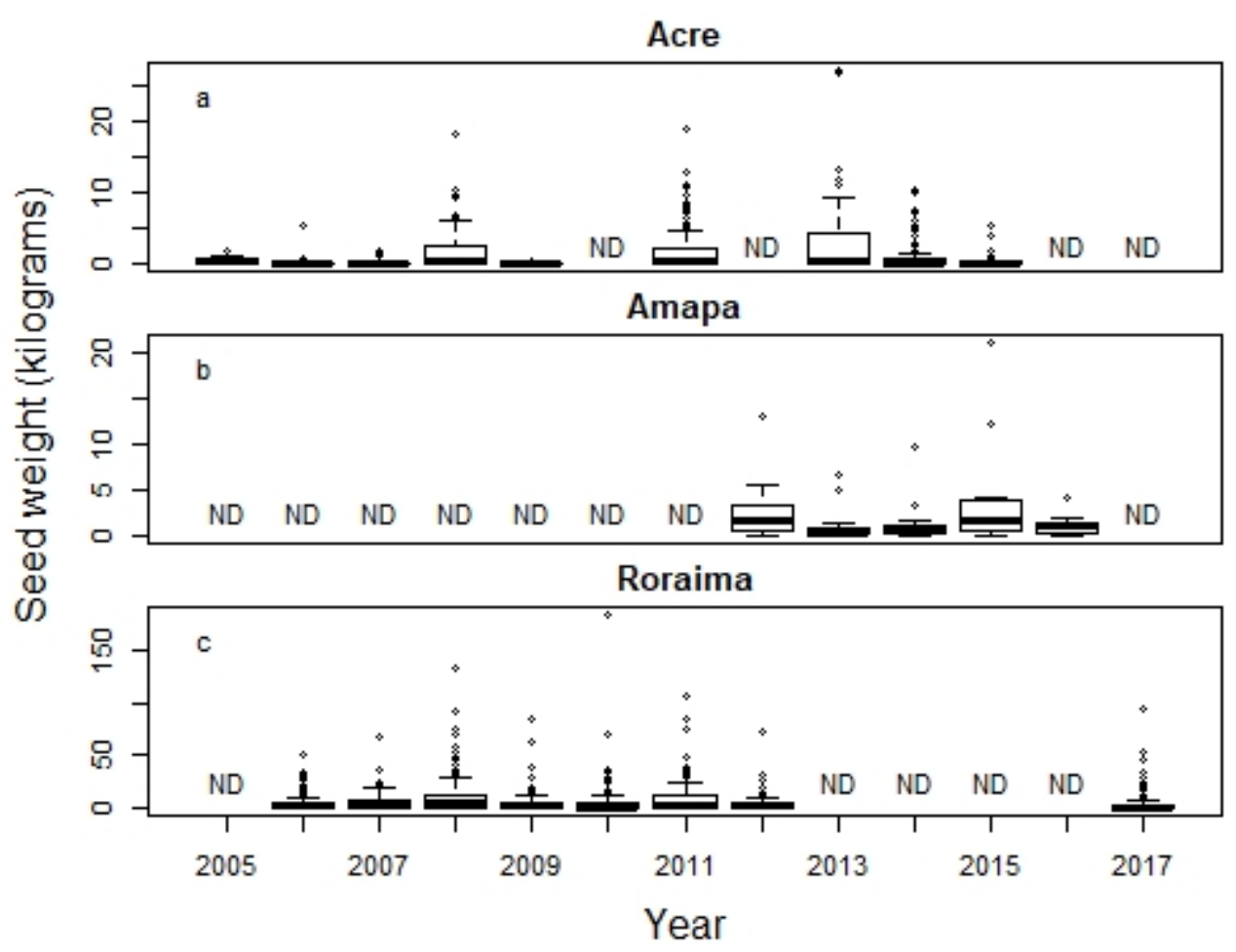

Figure 1. Boxplots of Carapa guianensis seed production (kilograms) by year are shown for the three study regions in the Brazilian Amazon: (a) Acre, (b) Amapá, and (c) Roraima. ND indicate years for which no data were collected at a specific site.
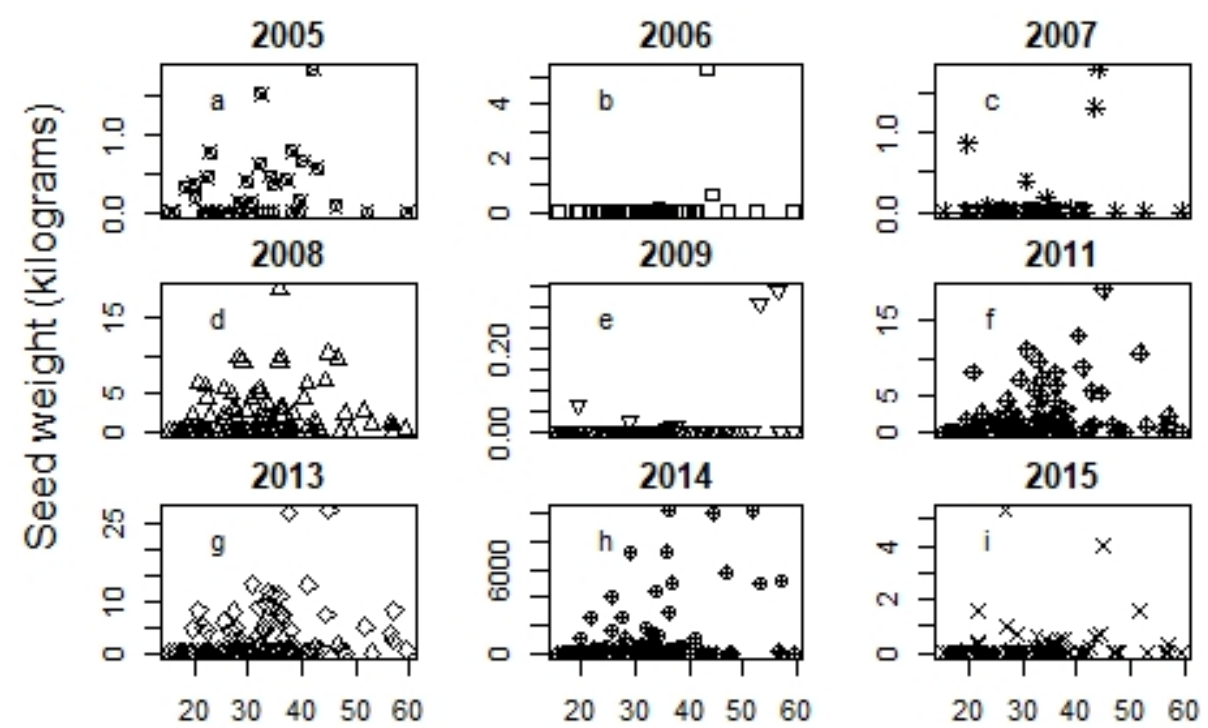

\section{Diameter at breast height}

Figure 2. Annual seed production (kilograms) by Carapa guianensis diameter at breast height in Acre Brazil in (a) 2005; (b) 2006; (c) 2007; (d) 2008; (e) 2009; (f) 2011; (g) 2013; (h) 2014; and (i) 2015.. 


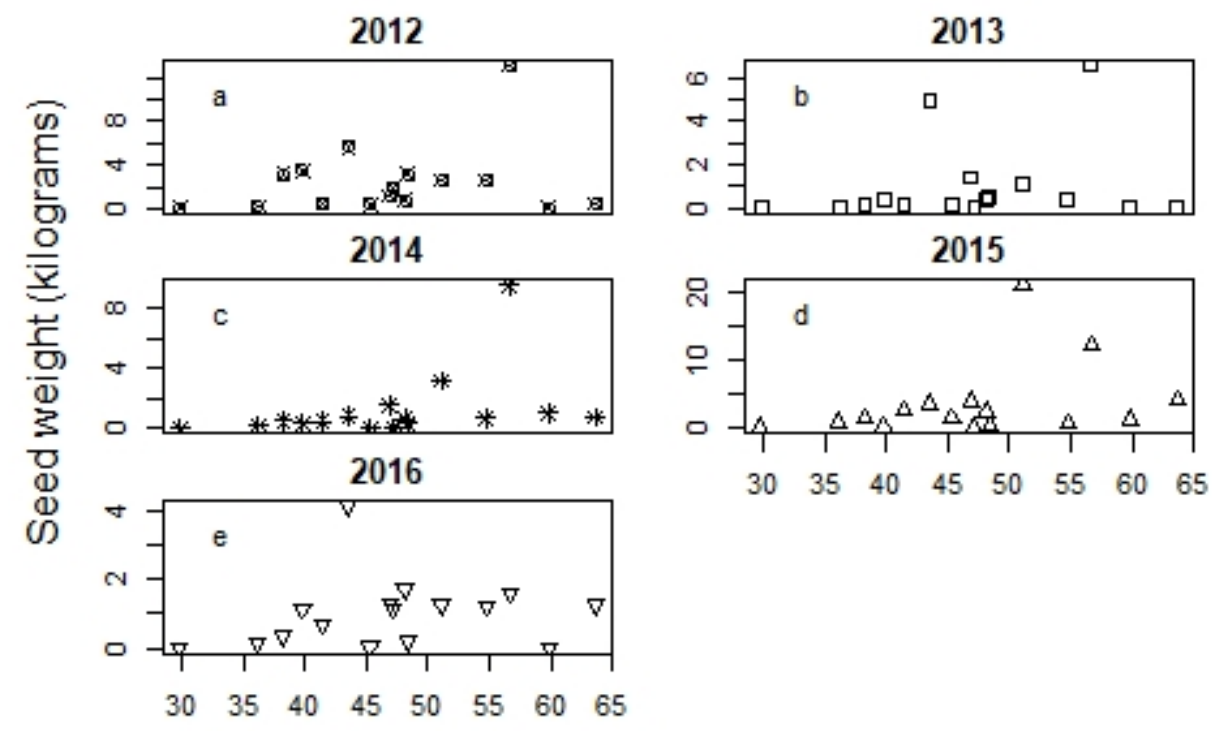

\section{Diameter at breast height}

Figure 3. Annual seed production (grams) by Carapa guianensis diameter at breast height in Amapá, Brazil in (a) 2012; (b) 2013; (c) 2014; (d) 2015; and (e) 2016.
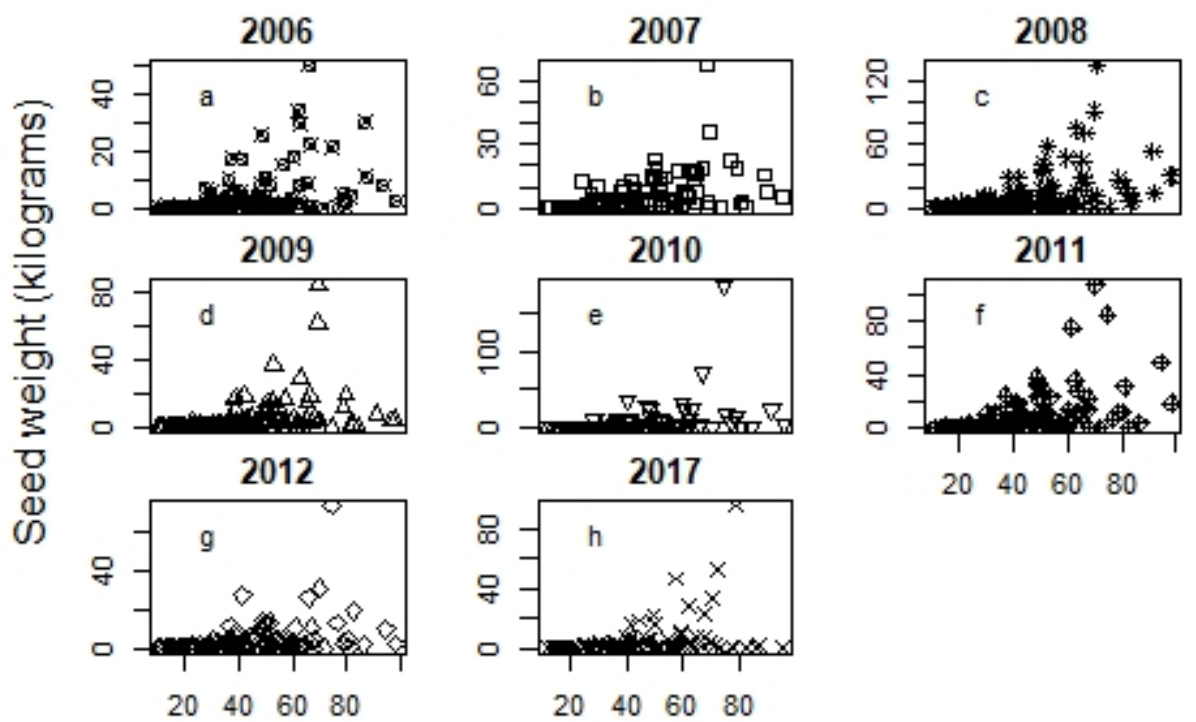

\section{Diameter at breast height}

Figure 4. Annual seed production (kilograms) by Carapa guianensis diameter at breast height in Roraima, Brazil in (a) 2006; (b) 2007; (c) 2008; (d) 2009; (e) 2010; (f) 2011; (g) 2012; and (h) 2017.

\subsection{Acre}

For Acre, the dbh, sum of wet season precipitation, and the sum of the previous year's wet season precipitation were all significant in increasing the proportion of trees producing seeds (1), the binomial component of the hurdle model. An increase in dry season precipitation (corresponding with a longer period with less than $100 \mathrm{~mm}$ monthly rainfall) and an increase in the annual average of the daily minimum temperature reduced the proportion of trees producing seeds in a given year (Table S2a). Moderate and weak La Niña events increased the proportion of trees producing seeds (Table S2b).

For those Carapa guianensis trees in Acre that produced in a given year, we found that the gamma or Weibull distribution were both appropriate for modeling the quantity of seeds (in grams) produced by those trees that had passed the hurdle and showed evidence 
of seed production. An increase in the previous year's wet season precipitation had a positive and significant effect on the quantity of seed production per tree (Table S3a). The El Niño Southern Oscillation was significant in predicting the quantity of seed production with weak and moderate La Niña events and all El Niño events (weak and very strong) having a positive and significant relationship with seed production quantity (Table S3b).

\subsection{Amapá}

Increased dry season precipitation significantly decreased the proportion of trees producing seeds (1) in Amapá (Table S4). For those trees in Amapá that produced in a given year, we found that the gamma or Weibull distributions were both appropriate. Increases in dbh and precipitation during the previous year's dry season corresponded with significant increases in seed production quantity in Amapá. Conversely, an increase in dry season precipitation during the year of seed production and daily minimum temperatures had significant negative effects on the quantity of seed production in that year (Table S5a). The El Niño Southern Oscillation was significant in predicting the quantity of seed production with weak La Niña and El Niño events having a negative and significant relationship with seed production quantity per tree (Table S5b).

\subsection{Roraima}

A larger diameter at breast height and dry season duration in the previous year significantly increased the proportion of C. guianensis trees producing seeds Roraima. Conversely, an increase in the previous year's dry season precipitation significantly decreased the proportion of C. guianensis trees producing seeds (Table S6a). The El Niño Southern Oscillation did not significantly influence the proportion of trees producing seeds (Table S6b).

For those trees in Roraima that produced in a given year, we found that the gamma distribution was appropriate for modeling the seed production quantity. An increase in $\mathrm{dbh}$ and both dry and wet season precipitation had a positive and significant effect on the quantity of seed production per tree in Roraima (Table S7a). Moderate and strong La Niña years had significant positive effects on the mass of seed production in Roraima (Table S7b).

\subsection{Comparison across Sites}

\subsubsection{Consistence in Masting Cues}

Cues for masting were not consistent across sites. While diameter at breast height was significant in determining tree reproductive status in both Acre and Roraima with an increase in dbh corresponding to an increased probability that an individual would produce seeds, this relationship was not evident at Amapá. There was a significant relationship between an increase in dry season precipitation and a decrease in the proportion of trees producing seeds in Acre and Amapá, but not Roraima. Similarly, an increase in wet season precipitation significantly increased the proportion of trees producing seeds at two of the sites (Table 2). However, the commonality in cues for masting ends with these shared predictors. Previous year dry and wet precipitation were not consistent across sites in its influence on the proportion of trees producing seeds. Temperature variables were correlated with other climate variables in Amapá and Roraima and were not included in the model so that limits the possibility for comparison of the effects of temperature across sites. 
Table 2. Summarizes the results from best fit models for estimating the probability that the zero threshold is crossed, or whether C. guianensis individuals do (1) or do not (0) produce seeds a the Acre, Amapá, and Roraima, Brazil sites (Binomial). The presence of fruit production was modeled both (a) using individual climate variables and (b) the combination of climate variables associated with the El Nino Southern Oscillation. Year and tree ID were modeled as random factors. For the ENSO years, $\mathrm{WL}=$ weak La Niña, ML = moderate La La Niña, SL = strong La Niña, WE = weak El Niño, and VS E = very strong El Niño. Results from best-fit models of the factors influencing the quantity of seed production per tree ( $\mathrm{g}$ ) at all three sites using a mixed model with a gamma distribution are also shown (Gamma). The quantity of fruit production was modeled both (a) using individual climate variables and (b) the combination of climate variables associated with the El Nino Southern Oscillation with year and individual tree (repeated measures) as random effects. Full models for each site can be seen in the Supplementary Materials. Positive effects are noted with a (+) and negative effects with a (-). Effects are significant at the $p<0.05$ level unless a $p$-value is noted alongside the direction of the effect. Absence of significant effects are noted with blanks.

\begin{tabular}{|c|c|c|c|c|c|c|}
\hline & $\begin{array}{c}\text { Acre- } \\
\text { Binomial }\end{array}$ & $\begin{array}{l}\text { Acre- } \\
\text { Gamma }\end{array}$ & $\begin{array}{l}\text { Amapá- } \\
\text { Binomial }\end{array}$ & $\begin{array}{c}\text { Amapá- } \\
\text { Gamma }\end{array}$ & $\begin{array}{c}\text { Roraima- } \\
\text { Binomial }\end{array}$ & $\begin{array}{c}\text { Roraima- } \\
\text { Gamma }\end{array}$ \\
\hline Diameter at breast height & $(+)$ & & & $\begin{array}{c}(+) \\
p=0.062\end{array}$ & $(+)$ & $(+)$ \\
\hline $\begin{array}{l}\text { Summed dry season } \\
\text { precipitation }\end{array}$ & $(-)$ & & $\begin{array}{c}(-) \\
p=0.098\end{array}$ & $(-)$ & & $(+)$ \\
\hline $\begin{array}{c}\text { Summed wet season } \\
\text { precipitation }\end{array}$ & $(+)$ & & na & & $(+)$ & $(+)$ \\
\hline $\begin{array}{c}\text { Previous year dry season } \\
\text { precipitation }\end{array}$ & & & na & $(+)$ & $(-)$ & \\
\hline $\begin{array}{c}\text { Previous year wet season } \\
\text { precipitation }\end{array}$ & $(+)$ & $(+)$ & na & & & \\
\hline $\begin{array}{l}\text { Annual average of the } \\
\text { daily minimum } \\
\text { temperature }\end{array}$ & $(-)$ & & na & na & na & na \\
\hline ENSO—SL & & & ND & ND & & $\begin{array}{c}(+) \\
p=0.064\end{array}$ \\
\hline ENSO-ML & $(+)$ & $(+)$ & ND & ND & & $(+)$ \\
\hline ENSO-WL & $(+)$ & $(+)$ & na & $(-)$ & & \\
\hline ENSO-VSE & $\begin{array}{c}(+) \\
p=0.096\end{array}$ & $(+)$ & na & ND & ND & ND \\
\hline ENSO-WE & & $(+)$ & na & $(-)$ & & \\
\hline
\end{tabular}

\subsubsection{Climate Attributes Influencing Quantity of Seeds per Tree}

Diameter at breast height also had a positive and significant effect on the quantity of seed produced per tree in Amapá and Roraima (if trees crossed the hurdle and reproduced in a given year), partially supporting our hypothesis that there would be a significant, positive relationship between dbh and seed production per tree. Wet season rainfall only had a significant effect on seed production quantity per tree at one site (Table 2), providing limited support for our hypothesis that wet season rainfall prior to flowering would be significantly and positively correlated with the total seed production per tree in that year.

\subsubsection{El Niño Southern Oscillation Effects on Seed Quantity}

We found support for a negative relationship between El Niño and seed quantity per tree only at Amapá. There was evidence for a positive relationship between the quantity of seeds produced and La Niña events at Acre and Roraima (Table 2). Limited years of data collection at Amapá means that there are no data on seed production at this site for some of the years when El Niño and La Niña events occurred. Table 2 shows the compiled results from Tables S2-S7 on factors influencing the probability that the zero threshold is 
crossed, or whether C. guianensis individuals produce seeds (1) and the quantity of seed production per tree (g) at the Acre, Amapá, and Roraima, Brazil research forests. The likelihood (binomial) and quantity of fruit production (gamma) were modeled both (a) using individual climate variables and (b) the combination of climate variables associated with the El Nino Southern Oscillation. For the ENSO years, WL = weak La Niña; SL = strong La Niña; and WE = weak El Niño. ND indicates no data for specific variables and na indicates the exclusion of variables due to their correlations with other variables or due to model non-convergence with their inclusion.

\section{Discussion}

Our research supports findings that climate cues predicting reproduction are not similar across regions and also lends support to the difficulty associated with comparing species' behavior across distinct habitats (floodplain, upland dry, and occasionally inundated forests). While other studies have found that climate cues differ regionally between species [31], our results indicate that for a single species, cues differ spatially. While peak C. guianensis fruitfall occurs during the rainy season in all three regions of the Brazilian Amazonian monitored in this study, the predictors of both whether trees produced and the quantify of seeds produced differed from region to region.

\subsection{Consistent Impact of dbh across Regions}

There is broad evidence for the importance of dbh in determining tree reproductive status [82]. Tree size determined the reproductive output in a wet tropical forest for approximately 2000 individuals of 17 species in a three-year study [56]. Our results provide support for the relationship between dbh and tree reproductive status in Acre and Roraima (Table 2). While this relationship was not apparent in Amapá, this was likely due to the selection of known reproductive trees for monitoring (and a smaller subset of trees selected due to the necessity of building enclosures for seed capture). Many studies have also found a significant and positive relationship between dbh and seed production quantity $[83,84]$, similar to the relationship in Roraima (Table 2). Research on an emergent tropical tree found that canopy crown size, a metric highly correlated with $\mathrm{dbh}$, was a stronger predictor of tree reproductive status and fruit production levels than $\mathrm{dbh}$ [83]. Once trees crossed a certain dbh threshold, the relationship between dbh and seed production quantity may weaken; a meta-analysis of North American trees found declining fecundity in large trees [85]. Indeed, dbh was a significant explanatory variable for seed production in Bertholletia excelsa Humb. \& Bonpl., but less so for large trees $(\geq 100 \mathrm{~cm}$ ) [83]. For the related Carapa procera DC. in Africa, the highest seed production occurred at sizes $>50 \mathrm{~cm}$ dbh [86]. However, in some species, seed production was the highest at intermediate sizes. For example, the seed production of a tropical timber tree increased up to $40-50 \mathrm{~cm}$ dbh, but not in larger dbh classes [74]. Additionally, research on the same $C$. guianensis study population in Acre found the highest seed production at an intermediate $\mathrm{dbh}[30]$. While the relationship between $\mathrm{dbh}$ and seed production was found across species [56], the contribution of individuals is highly unequal with some individuals consistently producing above average amounts while other individuals of reproductive size consistently did not produce [87]. Research on a long-lived shrub indicated that annual fecundity differences "became established early in the life of individuals and then persisted essentially unaltered until their death" [87]. For economically important species like C. guianensis, marking highly producing individuals early may be a practical way to monitor the onset of mast years by flower counts. Historical information on seed production per tree may also be useful in estimating the annual seed crop in mast years. Indeed, while seed production was variable between years (Figure 1a-c), using the lower bound of seed production in mast years might be a reasonable rule of thumb for estimating the potential production when flower counts indicate an expected mast year. This rule could be applied for a subset of the population on which seeds are collected or for the larger forest, depending on management goals. 


\subsection{Variable Precipitation Response Seen Across Regions}

We hypothesized that rainfall in both the year of flowering and the year prior to flowering would be significant determinants of $C$. guianensis seed production. At each site, either wet or dry season rainfall was significant in predicting the likelihood of seed production, but these effects were not consistent (Table 2). This lack of consistent relationship between the amount of rainfall and whether trees produced may be due to habitat differences. Amapá is a permanently humid floodplain forest. Forests in Acre and Roraima are both dry during the dry season and even the occasionally inundated forests in Acre are only temporarily flooded. Therefore, successive droughts in Acre and Roraima can increase water stress [53], limiting reproduction, and exacerbating tree mortality in extreme cases [88-91]. Indeed, research on an emergent tree found that direct air limited seed production, though this was mitigated when trees had more sapwood. Persistent dry conditions also (two consecutive rainfall years) had negative effects on production [83].

Time from the flower buds to ripe fruits was approximately 7 months in Amapá [39], up to 10 months in Roraima [46], and 10-11 months in Acre [30]. While rainfall during new leaf production could lower solar irradiance and reduce photosynthesis [53] and rainfall during flowering could disrupt pollination, plant water stress was likely more important in determining whether individuals produced as well as population-level masting in drier ecosystems (habitats). Higher dry season rainfall corresponding to longer dry season durations may have increased plant water stress. Increased dry season precipitation in the year prior to production also had a negative effect on whether or not trees produced in Roraima.

Rainfall is often inversely related to solar irradiance as the cloud cover that accompanies rainfall also limits the irradiance necessary for photosynthesis. Greater solar irradiance may relieve light limitation and increase net primary production [53] necessary for flower and fruit production. Therefore, increases in dry season rainfall may have reduced the net primary production necessary for flower and seed production, particularly at Amapá where water stress may have been reduced due to the flooded conditions in this ecosystem. These results provide evidence for the importance of understanding climate cues as "proximate drivers", factors directly impacting the processes by which flowers and seeds are produced [92] and how these climate cues might vary due to the underlying differences between regions (or study sites) [83]. Results also support the limited effect of climate variables in capturing all observed variability in fruit production [83] as well as providing clear evidence for different drivers of seed production in the regions studied [31]. Other studies have found that nutrients like P and K [83], or nutrient scarcity [93], are more significant in predicting both mast behavior and seed quantity. Therefore, unmeasured differences between the sites (i.e., soil oxygenation) might also be important predictive factors.

\subsection{Temperature}

There is substantial research on the effect of temperature on masting in temperate regions $[51,94]$. In forests without marked seasons, day length and temperature are often important abiotic factors triggering and synchronizing flowering $[49,65]$. Increases in the annual average daily minimum temperature had a negative and significant effect on whether trees produced in Acre (Table 2). Higher temperatures may increase plant water stress, especially when solar irradiance is high, leading to reductions in the photosynthetic update necessary for inflorescence development and seed production. We did not test whether a differential temperature cue $\Delta \mathrm{T}$, the difference between temperature during two previous summers, since this may be less pronounced for tropical regions with a year-round growing season [94] and due to the inability of this cue to be linked to a mechanism [92].

\subsection{El Niño Southern Oscillation}

While we discussed the influence of separate climate cues on C. guianensis, "communitywide ecological processes are probably not influenced by a single climate factor, but rather by a suite of climate variables accompanied by interactions among a suite of life-history 
strategies" [73]. The El Niño Southern Oscillation is one such example of coupled interactions that produce a suite of linked climate variables. The reduced rainfall and increased solar irradiance in moderate El Niño years can increase photosynthesis [41,53], subsequent flowering [52], and seed production [41,53]. More severe El Niño years, however, often have a negative effect with droughts leading to reductions in seed production. We saw this response in Amapá; weak El Niño events had a significant negative effect on the quantity of seeds produced per tree.

We hypothesized a negative relationship between El Niño and seed production and a corresponding positive relationship between La Niña and seed production independent of the masting phenomenon. The relationship between the quantity of seed production and ENSO, however, was more complicated than hypothesized. In addition to supporting research that weak El Niño events can favor seed production [53] in Acre, we also found the opposite relationship in Amapá. Similarly, we found contrasting responses for weak La Niña events across sites.

We think it likely that these differences are, in part, due to ENSO interactions with plant habitat. Generally, El Niño years are drier and warmer and La Niña years wetter and cooler in Amazonia with "relatively small and spatially heterogeneous" temperature variations [95]. In contrast, precipitation varies up to $20 \%$ of the "neutral annual rainfall" and differs regionally with less rainfall over northern Amazonia during El Niño years and more during La Niña years. In contrast, El Niño and La Niña years are both drier than normal in the southern Amazon basin [95]. Drier habitats, like terra firme forests coupled with lower annual rainfall, may lead to higher sensitivity to climate conditions. This would support results in Acre where three precipitation variables were significant in predicting whether trees produced. In Roraima, two precipitation variables were significant in predicting whether trees produced (Table S6 and Table 2. While forests in Roraima were considered terra firme, there was more rainfall than in Acre, potentially reducing plant water stress. Only one precipitation variable was significant in predicting whether trees reproduced in Amapá. As soils are permanently flooded, the plant environment was little changed by precipitation differences. Other research also indicates regional differences linked to regional climate; Pinus glauca Moench had evidence of local synchrony linked to summer temperatures but asynchrony at larger geographical scales $(>5000 \mathrm{~km})$ [96]. Our results illustrate the importance of considering the plant habitat alongside climate to better understand the individual and regional differences in seed production.

\subsection{Limitations from Seed Collection Methodology}

Seed removal may have occurred prior to the collection at the Acre and Roraima sites. Due to the expected high loss of seeds in the flooded forests of Amapá, nets were placed around all inventoried trees. Previous studies from this genus have used fruit husks to estimate the number of seeds [97], thus avoiding underestimating seed production in areas of high seed predation [98]. When this methodology was used for this species, however, due to the high production and inability to recreate each individual fruit, this methodology overestimated seedfall, likely due to the variability in the number of husks per fruit [30]. While low predator activity (due to hunting) in Acre and nets in Amapá likely reduced predation, this may not have been the case in Roraima where seed collection was less frequent and seed predators more prevalent (personal observation). Therefore, validating these seed estimates with other common methods of seed production quantification would be a useful addition to this work. Other studies have used binocular counts, seeds collected per ground surface relative to the crown area (where conspecific crowns are isolated and wind dispersal is limited), and seed traps (using the ratio of the group area covered by the trap to relative to the crown areas) [85].

\section{Conclusions and Implications for Management}

Better predictive models of mass-flowering events can help improve forest resource management [50]. This work is therefore an important contribution to understanding 
how climate cues play a role in the synchronous production and seed production quantity. Longer term measurements (an 11-year period in Acre and Roraima, and for 4 years and 8 months in Amapá) from three extreme regions of the Brazilian Amazon allowed for an analysis of whether climate cues were spatially consistent for this species. While there was no evidence of consecutive high production years, data collection gaps reduce our ability to support research indicating a physiological response of trees to resource limitation [93]. Our results indicating the differential impact of predictor variables of whether and how much production occurred are similar to other findings in the tropics [30,83] Europe [31], and Asia [50]. While there was a variability of seed production in response to most climate cues, we found a consistent positive effect of increasing $\mathrm{dbh}$ and the likelihood of a tree to produce as well as a positive relationship with dbh and seed production. Our results seem to indicate an interaction between habitat and climate cues. This interaction effect has been observed at the site level in other studies.

While the study results highlight some of the challenges in predicting synchronous flowering events, such as regional variability in tree response to climate cues, there are some key findings from this work that may help guide management for seed harvest. The first is that even for the same species, appropriate management strategies may differ regionally. Some consistent strategies could include marking highly producing individuals and maintaining trees of intermediate and high dbh. Perhaps coupled irradiance and flower monitoring can also assist managers in determining potential high production prior to fruit development. For C. guianensis $[15,18]$ and other economically important species, sharing research results with agro-extractivists living and working in forests [99], when coupled with their existing knowledge of Carapa guianensis seed management, may help better understand the periodicity and economic benefit of harvest, hopefully contributing to slowing deforestation from the ground up [26].

Work on monitoring production and better understanding the factors influencing years of high production should be coupled with linking forest managers to the markets where final goods will be sold. Linkages to international markets or cooperative ventures that allow the local sale of non-timber forest products, like $C$. guianensis seeds, to enterprises that create value-added products has the potential to create further incentives for forest management $[13,26]$ or conservation through use. Ecological knowledge is a first step toward effective species management, but for the economic viability of harvest, it is only a step [69] within a multi-faceted management strategy.

Supplementary Materials: The following are available online at https: / www.mdpi.com/article/10 $.3390 / \mathrm{f} 12060683 / \mathrm{s} 1$. Table S1: Climatic variables for each of the three Amazonian sites where Carapa guianensis seed production was measured. Data includes climatic variables during the study period and for the year preceding seed collection. Table S2: Best-fit model for estimating probability that the zero threshold is crossed, or whether C. guianensis individuals do (1) or do not produce seeds (0) at the Acre, Brazil research forest. The presence of fruit production was modeled both (a) using individual climate variables and (b) the combination of climate variables associated with the El Nino Southern Oscillation. Year and tree ID were modeled as random factors. Table S3: Best-fit model for modeling the factors influencing the quantity of seed production per tree (g) at the Acre, Brazil research forest. We used a mixed model with a gamma distribution to model seed production with year and individual tree (repeated measures) as random effects. The quantity of fruit production was modeled both (a) using individual climate variables and (b) the combination of climate variables associated with the El Nino Southern Oscillation. Table S4: Best-fit model for estimating probability that the zero threshold is crossed, or whether C. guianensis individuals do (1) or do not produce seeds (0) at the Amapá, Brazil research forest. The presence of fruit production was modeled both (a) using individual climate variables and (b) the combination of climate variables associated with the El Nino Southern Oscillation. Year and tree ID were modeled as random factors. Table S5: Best-fit model for modeling the factors influencing the quantity of seed production per tree (g) at the Amapá, Brazil research forest. The quantity of fruit production was modeled both (a) using individual climate variables and (b) the combination of climate variables associated with the El Nino Southern Oscillation. Table S6: Best-fit model for estimating probability that the zero threshold is crossed, or 
whether C. guianensis individuals do (1) or do not produce seeds (0) at the Roraima, Brazil research forest. The presence of fruit production was modeled both (a) using individual climate variables and (b) the combination of climate variables associated with the El Nino Southern Oscillation. Table S7: Best-fit model for modeling the factors influencing the quantity of seed production per tree (g) at the Roraima, Brazil research forest. The quantity of fruit production was modeled both (a) using individual climate variables and (b) the combination of climate variables associated with the El Nino Southern Oscillation.

Author Contributions: Conceptualization, C.A.K., L.H.d.O.W., C.V.d.C., A.C.L.-G., P.d.C. and.; methodology, C.A.K., L.H.d.O.W., A.C.L.-G., C.V.d.C., P.d.C., F.L.d.F.; formal analysis, C.A.K.; resources, C.A.K., L.H.d.O.W., C.V.d.C., P.d.C.; data curation, C.A.K.; writing-original draft preparation, C.A.K.; writing-review and editing, C.A.K., L.H.d.O.W., C.V.d.C., P.d.C.; visualization, C.A.K.; project administration, C.A.K.; funding acquisition, C.A.K., L.H.d.O.W., C.V.d.C., P.d.C. All authors have read and agreed to the published version of the manuscript.

Funding: This work was supported by the Brazilian Agricultural Research Corporation (EMBRAPA) through the Kamukaia III Project "Appreciation of non-timber forest products in the Amazon" (grant number SEG 12.13.07.007.00.00). During the preparation of this paper, C. Klimas was supported by a Faculty Summer Research Grant from DePaul University's College of Science and Health, USA.

Data Availability Statement: The data are available on request from the corresponding author.

Acknowledgments: We deeply appreciate the work of field technicians, interns, and all those who participated in seed quantification efforts at each of the three study sites. We want to thank Carmen Valencia for her work on initial data exploration and statistical analysis while supported by DePaul's Undergraduate Research Assistantship Program.

Conflicts of Interest: The authors declare no conflict of interest. The funders had no role in the design of the study; in the collection, analyses, or interpretation of data; in the writing of the manuscript, or in the decision to publish the results.

\section{References}

1. Alvarez-Berros, N.L.; Aide, T.M. Global demand for gold is another threat for tropical forests. Environ. Res. Lett. 2015, 10, 12. [CrossRef]

2. Arce, M.S. Resource Extraction and Protest in Peru; University of Pittsburgh Press: Pittsburgh, PA, USA, 2014.

3. Scullion, J.J.; Vogt, K.A.; Sienkiewicz, A.; Gmur, S.J.; Trujillo, C. Assessing the influence of land-cover change and conflicting land-use authorizations on ecosystem conversion on the forest frontier of madre de dios, peru. Biol. Conserv. 2014, 171, 247-258. [CrossRef]

4. Bowman, M.S.; Soares-Filho, B.S.; Merry, F.D.; Nepstad, D.C.; Rodrigues, H.; Almeida, O.T. Persistence of cattle ranching in the Brazilian Amazon: A spatial analysis of the rationale for beef production. Jlup Land Use Policy 2012, 29, 558-568. [CrossRef]

5. Ferrante, L.; Fearnside, P.M. Amazon sugar cane: A threat to the forest. Science 2018, 359, 1476.

6. Vijay, V.; Reid, C.D.; Finer, M.; Jenkins, C.N.; Pimm, S.L. Deforestation risks posed by oil palm expansion in the Peruvian Amazon. Environ. Res. Lett. 2018, 13, 10. [CrossRef]

7. Curtis, P.G.; Slay, C.M.; Harris, N.L.; Tyukavina, A.; Hansen, M.C. Classifying drivers of global forest loss. Science 2018, 361, 1108-1111. [CrossRef]

8. Ferrante, L.; Fearnside, P.M. The Amazon: Biofuels plan will drive deforestation. Nature 2020, 577, 170. [CrossRef] [PubMed]

9. Ferrante, L.; Fearnside, P.M. Brazil's new president and 'ruralists' threaten amazonia's environment, traditional peoples and the global climate comment. Environ. Conserv. 2019, 46, 261-263. [CrossRef]

10. Azevedo-Santos, V.M.; Fearnside, P.M.; Oliveira, C.S.; Padial, A.A.; Pelicice, F.M.; Lima, D.P.; Simberloff, D.; Lovejoy, T.E.; Magalhaes, A.L.B.; Orsi, M.L.; et al. Removing the abyss between conservation science and policy decisions in Brazil. Biodivers. Conserv. 2017, 26, 1745-1752. [CrossRef]

11. Godar, J.; Tizado, E.J.; Pokorny, B.; Johnson, J. Typology and characterization of Amazon colonists: A case study along the Transamazon highway. Hum. Ecol. 2012, 40, 251-267. [CrossRef]

12. Baraloto, C.; Alverga, P.; Quispe, S.B.; Barnes, G.; Chura, N.B.; da Silva, I.B.; Castro, W.; da Souza, H.; Moll, I.D.; Chilo, J.D.; et al. Trade-offs among forest value components in community forests of southwestern Amazonia. Ecol. Soc. 2014, 19, 11. [CrossRef]

13. Duchelle, A.E.; Guariguata, M.R.; Less, G.; Albornoz, M.A.; Chavez, A.; Melo, T. Evaluating the opportunities and limitations to multiple use of Brazil nuts and timber in western Amazonia. Ecol. Manag. 2012, 268, 39-48. [CrossRef]

14. Jaramillo-Giraldo, C.; Soares, B.; Ribeiro, S.M.C.; Goncalves, R.C. Is it possible to make rubber extraction ecologically and economically viable in the Amazon? The southern acre and chico mendes reserve case study. Ecol. Econ. 2017, 134, 186-197. [CrossRef] 
15. Klimas, C.M.; Cropper, W.P.; Kainer, K.A.; Wadt, L.H.D. Multimodel projections for evaluating sustainable timber and seed harvest of carapa guianensis. Science 2018, 64, 15-27.

16. Shanley, P.; da Serra Silva, M.; Melo, T.; Carmenta, R.; Nasi, R. From conflict of use to multiple use: Forest management innovations by small holders in Amazonian logging frontiers. Ecol. Manag. 2012, 268, 70-80. [CrossRef]

17. Shanley, P.; Pierce, A.R.; Laird, S.A.; Binnqüist, C.L.; Guariguata, M.R. From lifelines to livelihoods: Non-timber forest products into the 21st century. In Tropical Forestry Handbook; Springer: Berlin/Heidelberg, Germany, 2016; pp. $2713-2760$.

18. Klimas, C.A.; Cropper, W.P., Jr.; Kainer, K.A.; de Oliveira Wadt, L.H. Viability of combined timber and non-timber harvests for one species: A carapa guianensis case study. Ecol. Model. 2012, 246, 147-156. [CrossRef]

19. Wadt, L.H.O.; Kainer, K.A.; Staudhammer, C.L.; Serrano, R.O.P. Sustainable forest use Brazilian extractive reserves: Natural regeneradon of Brazil nut in exploited populations. Biol. Conserv. 2008, 141, 332-346. [CrossRef]

20. Zulu, D.; Ellis, R.H.; Culham, A. Collection, consumption, and sale of lusala (dioscorea hirtiflora) —A wild yam-by rural households in southern province, Zambia. Econ. Bot. 2019, 73, 47-63. [CrossRef]

21. Terborgh, J.; Peres, C.A. Do community-managed forests work? A biodiversity perspective. Land 2017, 6, 22. [CrossRef]

22. Carpenter, S.R. ; Millenium Ecosystem Assessment. Ecosystems and Human Well-Being: Scenarios: Findings of the Scenarios Working Group, Millennium Ecosystem Assessment; Island Press: Washington, DC, USA, 2005; Volume 2, p. 560.

23. Gomez-Baggethun, E.; de Groot, R.; Lomas, P.L.; Montes, C. The history of ecosystem services in economic theory and practice: From early notions to markets and payment schemes. Ecol. Econ. 2010, 69, 1209-1218. [CrossRef]

24. Engel, S.; Pagiola, S.; Wunder, S. Designing payments for environmental services in theory and practice: An overview of the issues. Ecol. Econ. 2008, 65, 663-674. [CrossRef]

25. Schwartzman, S.; Boas, A.V.; Ono, K.Y.; Fonseca, M.G.; Doblas, J.; Zimmerman, B.; Junqueira, P.; Jerozolimski, A.; Salazar, M.; Junqueira, R.P.; et al. The natural and social history of the indigenous lands and protected areas corridor of the Xingu River basin. Philos. Trans. R. Soc. B-Biol. Sci. 2013, 368, 12. [CrossRef]

26. Guariguata, M.R.; Cronkleton, P.; Duchelle, A.E.; Zuidema, P.A. Revisiting the 'cornerstone of Amazonian conservation': A socioecological assessment of Brazil nut exploitation. Biodivers. Conserv. 2017, 26, 2007-2027. [CrossRef]

27. Lopes, E.; Soares, B.; Souza, F.; Rajao, R.; Merry, F.; Ribeiro, S.C. Mapping the socio-ecology of non timber forest products (ntfp) extraction in the Brazilian Amazon: The case of acai (euterpe precatoria mart) in acre. Landsc. Urban Plann. 2019, 188, 110-117. [CrossRef]

28. Kainer, K.A.; Wadt, L.H.O.; Staudhammer, C.L. Explaining variation in Brazil nut fruit production. Ecol. Manag. 2007, 250, 244-255. [CrossRef]

29. Rockwell, C.A.; Guariguata, M.R.; Menton, M.; Arroyo Quispe, E.; Quaedvlieg, J.; Warren-Thomas, E.; Fernandez Silva, H.; Jurado Rojas, E.E.; Kohagura Arrunategui, J.A.H.; Meza Vega, L.A.; et al. Nut production in bertholletia excelsa across a logged forest mosaic: Implications for multiple forest use. PLoS ONE 2015, 10, e0135464. [CrossRef] [PubMed]

30. Klimas, C.A.; Kainer, K.A.; Wadt, L.H.; Staudhammer, C.L.; Rigamonte-Azevedo, V.; Correia, M.F.; da Silva Lima, L.M. Control of carapa guianensis phenology and seed production at multiple scales: A five-year study exploring the influences of tree attributes, habitat heterogeneity and climate cues. J. Trop. Ecol. 2012, 28, 105-118. [CrossRef]

31. Nussbaumer, A.; Waldner, P.; Apuhtin, V.; Aytar, F.; Benham, S.; Bussotti, F.; Eichhorn, J.; Eickenscheidt, N.; Fabianek, P.; Falkenried, L.; et al. Impact of weather cues and resource dynamics on mast occurrence in the main forest tree species in Europe. Ecol. Manag. 2018, 429, 336-350. [CrossRef]

32. Kelly, D.; Sork, V.L. Mast seeding in perennial plants: Why, how, where? Annu. Rev. Ecol. Syst. 2002, 33, 427-447. [CrossRef]

33. Herrero-Jauregui, C.; Garcia-Fernandez, C.; Sist, P.L.J.; Casado, M.A. Conflict of use for multi-purpose tree species in the state of para, eastern Amazonia, Brazil. Biodivers. Conserv. 2009, 18, 1019-1044. [CrossRef]

34. Herrero-Jauregui, C.; Guariguata, M.R.; Cardenas, D.; Vilanova, E.; Robles, M.; Licona, J.C.; Nalvarte, W. Assessing the extent of "conflict of use" in multipurpose tropical forest trees: A regional view. J. Environ. Manag. 2013, 130, 40-47. [CrossRef]

35. dos Santos, A.J. Aspectos econômicos da cadeia produtiva dos óleos de andiroba (carapa guianensis aubl.) e copaíba (copaifera multijuga hayne) na floresta nacional do tapajós-pará. FlorestaCuritiba 2010, 40, 23-28. [CrossRef]

36. Shanley, P.; Medina, G. Frutíferas e Plantas Úteis na Vida Amazônica; CIFOR \& Imazon: Belém, Brazil, 2005.

37. Henriques, M.; Penido, C. The therapeutic properties of carapa guianensis. Cpd Curr. Pharm. Des. 2014, 20, 850-856. [CrossRef]

38. Praciak, A. The Cabi Encyclopedia of Forest Trees; Center for Agriculture and Bioscience International: Boston, MA, USA, 2013.

39. Dantas, A.R.; Lira-Guedes, A.C.; Mustin, K.; Aparicio, W.C.S.; Guedes, M.C. Phenology of the multi-use tree species carapa guianensis in a floodplain forest of the Amazon estuary. Acta Bot. Bras. 2016, 30, 618-627. [CrossRef]

40. Londres, M. Diagnóstico Participativo do Sistema Produtivo da Andiroba (Carapa sp.) e Estudo Botânico da Espécie nas Comunidades São Joãodo, Jaburu e Fortaleza do Jaburu, município de Gurupá. Bachelor's Thesis, Universidade de São Paulo, Piracicaba, Brazil, 2004.

41. Detto, M.; Wright, S.J.; Calderon, O.; Muller-Landau, H.C. Resource acquisition and reproductive strategies of tropical forest in response to the El Nino-southern oscillation. Nat. Commun. 2018, 9, 8. [CrossRef] [PubMed]

42. Vanschaik, C.P.; Terborgh, J.W.; Wright, S.J. The phenology of tropical forests-Adaptive significance and consequences for primary consumers. Annu. Rev. Ecol. Syst. 1993, 24, 353-377. [CrossRef]

43. Mendoza, I.; Condit, R.S.; Wright, S.J.; Caubere, A.; Chatelet, P.; Hardy, I.; Forget, P.M. Inter-annual variability of fruit timing and quantity at nouragues (french guiana): Insights from hierarchical bayesian analyses. Biotropica 2018, 50, 431-441. [CrossRef] 
44. da Luz Freitas, J.; dos Santos, A.C.; Silva, R.B.L.; Rabelo, F.G.; dos Santos, E.S.; de Lima Silva, T. Fenologia reprodutiva da espécie carapa guianensis aubl. (andirobeira) em ecossistemas de terra firme e várzea, amapá, brasil. Biota Amaz. 2013, 3, 31-38. [CrossRef]

45. Maués, M. Estratégias Reprodutivas de Espécies Arbóreas e a Sua Importância Para o Manejo e Conservação Florestal: Floresta Nacional do Tapajós (Belterra-Pa); Universidade de Brasilia: Brasilia, Brazil, 2006.

46. Pereira, M.R.N.; Tonini, H. Fenologia da andiroba ( carapa guianensis, aubl., meliaceae) no sul do estado de roraima. Ciência Florest 2012, 22, 47-58. [CrossRef]

47. Boufleuer, N.T. Aspectos Ecológicos de Andiroba (Carapa Guianensis Aublet., Meliaceae), Como Subsídio ao Manejo e Conservação; Universidade Federal do Acre: Rio Branco, Brazil, 2004.

48. Plowden, C. The ecology and harvest of andiroba seeds for oil production in the Brazilian Amazon. Conserv. Soc. 2004, 2, 251-272.

49. Wright, S.J.; Vanschaik, C.P. Light and the phenology of tropical trees. Am. Nat. 1994, 143, 192-199. [CrossRef]

50. Chechina, M.; Hamann, A. Climatic drivers of dipterocarp mass-flowering in South-East Asia. J. Trop. Ecol. 2019, 35, 108-117. [CrossRef]

51. Bogdziewicz, M.; Szymkowiak, J.; Fernandez-Martinez, M.; Penuelas, J.; Espelta, J.M. The effects of local climate on the correlation between weather and seed production differ in two species with contrasting masting habit. Agric. Meteorol. 2019, 268, 109-115. [CrossRef]

52. Kiladis, G.N.; Diaz, H.F. Global climatic anomalies associated with extremes in the southern oscillation. J. Clim. 1989, 2, 1069-1090. [CrossRef]

53. Wright, S.J.; Calderon, O. Seasonal, El Nino and longer term changes in flower and seed production in a moist tropical forest. Ecol. Lett. 2006, 9, 35-44. [CrossRef] [PubMed]

54. Nepstad, D.; Lefebvre, P.; Da Silva, U.L.; Tomasella, J.; Schlesinger, P.; Solorzano, L.; Moutinho, P.; Ray, D.; Benito, J.G. Amazon drought and its implications for forest flammability and tree growth: A basin-wide analysis. Glob. Chang. Biol. 2004, 10, 704-717. [CrossRef]

55. Williamson, G.B.; Laurance, W.F.; Oliveira, A.A.; Delamonica, P.; Gascon, C.; Lovejoy, T.E.; Pohl, L. Amazonian tree mortality during the $1997 \mathrm{El}$ Nino drought. Conserv. Biol. 2000, 14, 1538-1542. [CrossRef]

56. Minor, D.M.; Kobe, R.K. Fruit production is influenced by tree size and size-asymmetric crowding in a wet tropical forest. Ecol. Evol. 2019, 9, 1458-1472. [CrossRef] [PubMed]

57. Wright, S.J.; Jaramillo, M.A.; Pavon, J.; Condit, R.; Hubbell, S.P.; Foster, R.B. Reproductive size thresholds in tropical trees: Variation among individuals, species and forests. J. Trop. Ecol. 2005, 21, 307-315. [CrossRef]

58. Riba-Hernandez, P.; Segura, J.L.; Munoz-Valverde, J. Female fruit production depends on female flower production and crown size rather than male density in a continuous population of a tropical dioecious tree (virola surinamensis). Am. J. Bot. 2016, 103, 1990-1999. [CrossRef]

59. O'Brien, M.J.; Perez-Aviles, D.; Powers, J.S. Resilience of seed production to a severe El Nino-induced drought across functional groups and dispersal types. Glob. Chang. Biol. 2018, 24, 5270-5280. [CrossRef]

60. Tonini, H.; da Costa, P.; Kamiski, P.E. Estrutura, distribuição espacial e produção de sementes de andiroba (carapa guianensis aubl.) no sul do estado de roraima. Ciência Florest. 2009, 19, 247-255. [CrossRef]

61. McHargue, L.A.; Hartshorn, G.S. Seed and seedling ecology of carapa-guianensis. Turrialba 1983, 33, $399-404$.

62. Pennington, T.D.; Styles, B.T.; Taylor, D.A.H. Meliaceae, with accounts of swietenioideae and chemotaxonomy. Flora Neotrop. 1981, 28, 1-470.

63. Ferraz, I.D.K.; Camargo, J.L.C.; de Tarso Barbosa Sampaio, P. Sementes e plantulas de andiroba, carapa guianensis aubl. E carapa procera d. C.: Aspectos botanicos, ecologicos e tecnologicos. Acta Amaz. (Manaus) 2002, 32, 647-661.

64. Klimas, C.A.; Kainer, K.A.; Wadt, L.H.O. Population structure of carapa guianensis in two forest types in the southwestern Brazilian Amazon. Ecol. Manag. 2007, 250, 256-265. [CrossRef]

65. Stevenson, P.R.; Quinones, M.J.; Ahumada, J.A. Annual variation in fruiting pattern using two different methods in a lowland tropical forest, Tinigua National Park, Colombia. Biotropica 1998, 30, 129-134. [CrossRef]

66. de Jesus-Barros, C.R.; Lira-Guedes, A.C.; Guedes, M.C.; Guabiraba-Ribeiro, G.; Barbosa, E.D. Record of the occurrence of hypsipyla ferrealis e hypsipyla grandella (lepidoptera: Pyralidae) in crabwood carapa guianensis, meliaceae) in macapa, ap-Brazil. Cienc. Florest. 2015, 25, 765-769.

67. Guariguata, M.R.; Garcia-Fernandez, C.; Sheil, D.; Nasi, R.; Herrero-Jauregui, C.; Cronkleton, P.; Ingram, V. Compatibility of timber and non-timber forest product management in natural tropical forests: Perspectives, challenges, and opportunities. Ecol. Manag. 2010, 259, 237-245. [CrossRef]

68. Fazolin, M.; Estrela, J.L.V.; Júnior, D.L.A.; de SÁ Pessoa, J. Avaliação do Uso do óleo de Andiroba, Carapa Guianensis Aubl., no Controle da Cerotoma Tingomarianus Bechyné em Feijoeiro no Acre; Congresso Brasileiro de Defensivos Agrícolas Naturais, Fortaleza, Ceará; Academia Paraense de Ciências: Fortaleza, Brazil, 2000.

69. Klimas, C.A.; Kainer, K.A.; de Oliveira Wadt, L.H. The economic value of sustainable seed and timber harvests of multi-use species: An example using carapa guianensis. Ecol. Manag. 2012, 268, 81-91. [CrossRef]

70. Instituto Nacional de Meteorologia. Estações Automáticas; Instituto Nacional de Meteorologia: Brasília, Brazil, 2019.

71. Costa, M.H.; Pires, G.F. Effects of Amazon and central Brazil deforestation scenarios on the duration of the dry season in the arc of deforestation. Int. J. Climatol. 2010, 30, 1970-1979. [CrossRef] 
72. Newbery, D.M.; Chuyong, G.B.; Zimmermann, L. Mast fruiting of large ectomycorrhizal african rain forest trees: Importance of dry season intensity, and the resource-limitation hypothesis. New Phytol. 2006, 170, 561-579. [CrossRef]

73. Wang, Y.Y.; Zhang, J.; LaMontagne, J.M.; Lin, F.; Li, B.H.; Ye, J.; Yuan, Z.Q.; Wang, X.G.; Hao, Z.Q. Variation and synchrony of tree species mast seeding in an old-growth temperate forest. J. Veg. Sci. 2017, 28, 413-423. [CrossRef]

74. Fonseca, M.G.; Vidal, E.; dos Santos, F.A.M. Intraspecific variation in the fruiting of an Amazonian timber tree: Implications for management. Biotropica 2009, 41, 179-185. [CrossRef]

75. Bolker, B.M.; Brooks, M.E.; Clark, C.J.; Geange, S.W.; Poulsen, J.R.; Stevens, M.H.; White, J.S. Generalized linear mixed models: A practical guide for ecology and evolution. Trends Ecol. Evol. 2009, 24, 127-135. [CrossRef] [PubMed]

76. Lewin, W.C.; Freyhof, J.; Huckstorf, V.; Mehner, T.; Wolter, C. When no catches matter: Coping with zeros in environmental assessments. Ecol. Indic. 2010, 10, 572-583. [CrossRef]

77. Zuur, A.F.; Ieno, E.N.; Walker, N.J.; Saveliev, A.A.; Smith, G.M. Mixed Effect Models and Extensions in Ecology with R; Springer: New York, NY, USA, 2009; p. 574.

78. Delignette-Muller, M.L.; Dutang, C. Fitdistrplus: An r package for fitting distributions. J. Stat. Softw. 2015, 64, 1-34. [CrossRef]

79. Kooperberg, C. Logspline: Routines for Logspline Density Estimation; 2020; Available online: https://cran.r-project.org/web/ packages/logspline/logspline.pdf (accessed on 15 May 2021).

80. R Development Core Team. R: A Language and Environment for Statistical Computing; R Foundation for Statistical Computing: Vienna, Austria, 2016.

81. Brooks, M.E.; Kristensen, K.; van Benthem, K.J.; Magnusson, A.; Berg, C.W.; Nielsen, A.; Skaug, H.J.; Mächler, M.; Bolker, B.M. Glmmtmb balances speed and flexibility among packages for zero-inflated generalized linear mixed modeling. $R$ J. 2017, 9, 377-399. [CrossRef]

82. Nabe-Nielsen, J.; Kollmann, J.; Pena-Claros, M. Effects of liana load, tree diameter and distances between conspecifics on seed production in tropical timber trees. Ecol. Manag. 2009, 257, 987-993. [CrossRef]

83. Staudhammer, C.L.; Wadt, L.H.O.; Kainer, K.A.; da Cunha, T.A. Comparative models disentangle drivers of fruit production variability of an economically and ecologically important long-lived Amazonian tree. Sci. Rep. 2021, 11, 2563. [CrossRef] [PubMed]

84. Thomas, E.; Valdivia, J.; Caicedo, C.A.; Quaedvlieg, J.; Wadt, L.H.O.; Corvera, R. NTFP harvesters as citizen scientists: Validating traditional and crowdsourced knowledge on seed production of Brazil nut trees in the Peruvian Amazon. PLoS ONE 2017, 12, 1-20. [CrossRef] [PubMed]

85. Clark, J.S.; Andrus, R.; Aubry-Kientz, M.; Bergeron, Y.; Bogdziewicz, M.; Bragg, D.C.; Brockway, D.; Cleavitt, N.L.; Cohen, S.; Courbaud, B.; et al. Continent-wide tree fecundity driven by indirect climate effects. Nat. Commun. 2021, 12, 11.

86. Lankoande, B.; Ouedraogo, A.; Boussim, J.I.; Lykke, A.M. Identification of determining traits of seed production in carapa procera and pentadesma butyracea, two native oil trees from riparian forests in burkina faso, west africa. Biomass Bioenerg. 2017, 102, 37-43. [CrossRef]

87. Herrera, C.M.; Jovani, R. Lognormal distribution of individual lifetime fecundity: Insights from a 23-year study. Ecology 2010, 91, 422-430. [CrossRef]

88. Cochrane, M.A.; Alencar, A.; Schulze, M.D.; Souza, C.M.; Nepstad, D.C.; Lefebvre, P.; Davidson, E.A. Positive feedbacks in the fire dynamic of closed canopy tropical forests. Science 1999, 284, 1832-1835. [CrossRef] [PubMed]

89. da Silva, S.S.; Fearnside, P.M.; Graca, P.; Brown, I.F.; Alencar, A.; de Melo, A.W.F. Dynamics of forest fires in the southwestern Amazon. Ecol. Manag. 2018, 424, 312-322. [CrossRef]

90. Grogan, J.; Galvão, J. Physiographic and floristic gradients across topography in transitional seasonally dry evergreen forests of southeast Pará, Brazil. Acta Amaz. 2006, 36, 483-496. [CrossRef]

91. Grogan, J.; Schulze, M. The impact of annual and seasonal rainfall patterns on growth and phenology of emergent tree species in southeastern Amazonia, Brazil. Biotropica 2012, 44, 331-340. [CrossRef]

92. Pearse, I.S.; Koenig, W.D.; Knops, J.M.H. Cues versus proximate drivers: Testing the mechanism behind masting behavior. Oikos 2014, 123, 179-184. [CrossRef]

93. Fernandez-Martinez, M.; Pearse, I.; Sardans, J.; Sayol, F.; Koenig, W.D.; LaMontagne, J.M.; Bogdziewicz, M.; Collalti, A.; Hacket-Pain, A.; Vacchiano, G.; et al. Nutrient scarcity as a selective pressure for mast seeding. Nat. Plants 2019, 5, 1222-1228. [CrossRef]

94. Kelly, D.; Geldenhuis, A.; James, A.; Holland, E.P.; Plank, M.J.; Brockie, R.E.; Cowan, P.E.; Harper, G.A.; Lee, W.G.; Maitland, M.J.; et al. Of mast and mean: Differential-temperature cue makes mast seeding insensitive to climate change. Ecol. Lett. 2013, 16, 90-98. [CrossRef]

95. Jonathan, A.F.; Aurélie, B.; Michael, T.C.; Marcos Heil, C. El niño-southern oscillation and the climate, ecosystems and rivers of Amazonia. Glob. Biogeochem. Cycles 2002, 16, 79-1.

96. LaMontagne, J.M.; Pearse, I.S.; Greene, D.F.; Koenig, W.D. Mast seeding patterns are asynchronous at a continental scale. Nat. Plants 2020, 6, 460-465. [CrossRef] [PubMed]

97. Forget, P.M. Removal of seeds of carapa procera (meliaceae) by rodents and their fate in rainforest in French guiana. J. Trop. Ecol. 1996, 12, 751-761. [CrossRef] 
98. Vander Wall, S.B.; Kuhn, K.M.; Beck, M.J. Seed removal, seed predation, and secondary dispersal. Ecology 2005, 86, 801-806. [CrossRef]

99. de Jong, W.; Galloway, G.; Katila, P.; Pacheco, P. Incentives and constraints of community and smallholder forestry. For. For. 2016, 7, 209. [CrossRef] 